\title{
Peningkatan Produksi Temulawak (Curcuma xanthorrhiza) Pada Berbagai Macam Pola Tanam dengan Jagung (Zea mays)
}

\section{Increasing Temulawak (Curcuma xanthorrhiza) Production In Different Cropping Pattern With Maize (Zea mays)}

\author{
Wisnu Eko Murdiono ${ }^{1 *}$, Ellis Nihayati ${ }^{1}$, Sitawati $^{1}$ dan Nur Azizah ${ }^{1}$ \\ Diterima ....2016/Disetujui .... Januari 2016
}

\begin{abstract}
Temulawak is one of Indonesia's indigenous plant which is rarely cultivated by farmers because it has a long harvest time and wide plant spacing. Intercropping temulawak with maize is expected to attract farmers to cultivate temulawak intensively. This research was aimed at obtaining the most advantageous growth and yield of temulawak (Curcuma xanthorrhiza) in different planting patterns with maize (Zea mays). This research was conducted at the Faculty of Agriculture Brawijaya University experimental farm in Jatikerto, Malang, from December 2014 to June 2015. Experimental design was completely randomized block design with four replication and 6 treatments : T1 (strip cropping, cropping simultaneously), T2 (row cropping, cropping simultaneously), T3 (strip relay cropping, planting 1 month before the maize), T4 (row relay cropping, planting 1 month before the maize), T5 (strip relay cropping, planting 1 month after the maize), T6 (row relay cropping, planting 1 month after the maize). The growth and yield of temulawak were significantly affected by planting pattern and planting time of maize. Generally, earlier and simultaneously planted temulawak had higher growth and yield. Row cropping is the best planting pattern of turmeric combined with maize which produce 4.05 ton ha $a^{-1}$ fresh rhizome weight.
\end{abstract}

Keywords : intercropping, maize, planting pattern, planting time, turmeric

\begin{abstract}
ABSTRAK
Waktu panen yang lama serta jarak tanam yang lebar menyebabkan kurangnya minat petani untuk menanam temulawak sebagai tanaman utama. Salah satu solusi yang diharapkan untuk menarik minat petani dalam membudidayakan temulawak adalah dengan pola tanam tumpang sari dengan tanaman pangan. Jagung umumnya memiliki waktu panen relatif lebih singkat dan jarak tanam relatif sempit sehingga potensial untuk ditumpangsarikan dengan temulawak. Tujuan penelitian ini ialah untuk mendapatkan pola tanam yang memberikan pertumbuhan dan hasil terbaik bagi temulawak pada beberapa pola tanam tumpangsari dengan jagung. Penelitian ini dilakukan di Kebun Percobaan Fakultas Pertanian, Universitas Brawijaya yang berlokasi di Desa Jatikerto, Malang pada bulan Desember 2014 sampai Juni 2015. Penelitian ini menggunakan Rancangan Acak Kelompok yang diulang sebanyak 4 kali, dengan 6 perlakuan pola tanam sebagai berikut: T1 (strip cropping, ditanam bersamaan), T2 (pola row cropping, ditanam bersamaan), T3 (strip relay temulawak - jagung), T4 (row relay temulawak - jagung), T5 (strip relay jagung temulawak), T6 (row relay jagung - temulawak). Hasil penelitian menunjukkan bahwa perbedaan pola tanam pada sistem tumpangsari temulawak dan jagung memberikan pengaruh yang berbeda bagi pertumbuhan dan hasil temulawak. Temulawak yang ditanam lebih awal memiliki nilai rata-rata pertumbuhan dan hasil yang lebih baik jika dibandingkan dengan temulawak yang ditanam setelah jagung. Pola tanam row cropping memberikan hasil rimpang temulawak tertinggi pada berbagai macam pola tanam dengan jagung yang mencapai 4.05 ton ha $\mathrm{h}^{-1}$.
\end{abstract}

Kata kunci: jagung, pola tanam, produksi, temulawak, tumpangsari

${ }^{1}$ Fakultas Pertanian Universitas Brawijaya Malang

Jalan Veteran Malang, Jawa Timur 65145.

Email: denmaswisnu@yahoo.com (*penulis korespondensi) 


\section{PENDAHULUAN}

Temulawak (Curcuma xanthorrhiza Roxb. Synm. Curcuma javanica) adalah tanaman obat asli Indonesia (Nihayati et al., 2013). Temulawak merupakan salah satu tanaman obat unggulan yang memiliki khasiat multifungsi. Rimpangnya mengandung kurkumin, zat yang berkhasiat untuk mengatasi berbagai penyakit, seperti kelainan pada hati/lever, kantong empedu, dan pankreas. Selain itu juga dapat berkhasiat untuk menambah nafsu makan, menurunkan kadar kolesterol dalam darah, meningkatkan sistem immunitas tubuh, anti bakteri, anti diabetik, anti hepatotoksik, anti inflamasi, anti oksidan, anti tumor, diuretika dan depresan (Akamine et al., 2007).

Jangka waktu panen yang cukup lama dan jarak tanam temulawak yang lebar menyebabkan para petani enggan menanam tanaman temulawak sebagai tanaman utama (Rahardjo, 2010). Tumpangsari temulawak dengan tanaman semusim, seperti padi gogo dan kacang tanah (Syakir et al., 2008), serta dengan jagung diharapkan dapat menarik minat petani daerah penghasil temulawak untuk menanam temulawak karena pendapatan petani akan bertambah dan lebih menguntungkan secara ekonomis. Temulawak memiliki umur panen yang panjang yaitu 9-12 bulan (Rahardjo, 2010), sedangkan tanaman jagung memiliki umur panen yang relatif pendek yaitu 3-4 bulan, sehingga hasil dari tanaman jagung dapat memenuhi kebutuhan hidup petani disela menunggu panen temulawak. Selain itu, jarak tanam yang cukup lebar bagi temulawak (Rahardjo dan Ekawasita, 2010) dan jarak tanam yang relatif sempit bagi jagung (Hasan, 2013) dapat menjadi potensi untuk melakukan tumpangsari pada kedua tanaman tersebut.

Budidaya tanaman secara tumpangsari dapat meningkatkan produksi per satuan luas lahan, namun dalam sistem ini memungkinkan terjadinya kompetisi di antara tanaman utama dan tanaman sela yang dapat mengakibatkan penurunan produktivitas salah satu tanaman. Masing-masing tanaman harus memiliki ruang yang cukup untuk memaksimumkan kerjasama (cooperation) dan meminimumkan kompetisi (competition). Semakin tinggi kerapatan suatu pertanaman dapat mengakibatkan semakin besarnya tingkat persaingan antar tanaman dalam mendapatkan unsur hara maupun cahaya. Selain itu, umur periode kritis juga merupakan salah satu faktor yang menentukan keberhasilan tumpangsari, karena berpengaruh terhadap kemampuan tanaman dalam berkompetisi (Priambodo et al., 2010). Oleh karena itu, dalam sistem tumpangsari perlu dicari model yang tepat, sehingga dapat mempertahankan produktivitas tanaman utama dan sela dalam meminimalisir efek kompetisi (Suwarto et al., 2005).

\section{BAHAN DAN METODE}

Penelitian ini dilaksanakan di kebun percobaan Fakultas Pertanian Brawijaya Desa Jatikerto, Kecamatan Kromengan, Kabupaten Malang; dengan ketinggian tempat $300 \mathrm{mdpl}$ serta suhu berkisar antara $27-31{ }^{\circ} \mathrm{C}$, dimulai pada bulan Desember 2014 sampai Juni 2015.

Bahan tanam yang digunakan dalam penelitian ini adalah temulawak klon UB2 dan benih jagung hibrida, kemudian pupuk urea $(46 \% \mathrm{~N}) 300 \mathrm{~kg} \cdot \mathrm{ha}^{-1}, \mathrm{SP} 36\left(36 \% \mathrm{P}_{2} \mathrm{O}_{5}\right) 100$

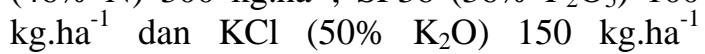
sebagai sumber unsur hara $\mathrm{N}, \mathrm{P}$ dan $\mathrm{K}$. Rimpang temulawak yang dijadikan benih ditunaskan terlebih dahulu. Setelah tunas muncul, rimpang dipotong menyisakan satu mata tunas dengan bobot basah $+10 \mathrm{~g} /$ benih, kemudian benih disemaikan lagi sampai panjang tunas $+5 \mathrm{~cm}$ dan benih siap ditanam. Setelah benih siap, anak rimpang temulawak ditanam dengan posisi tunas muncul di atas permukaan tanah. Benih jagung ditanam dengan cara ditugal masing-masing 2 benih per lubang tanam.

Penelitian ini menggunakan Rancangan Acak Kelompok (RAK) dengan 4 ulangan dan 6 perlakuan pola tanam, yaitu: $\mathrm{T} 1=$ strip cropping, $\mathrm{T} 2=$ row cropping, $\mathrm{T} 3=$ strip relay temulawak - jagung, $\mathrm{T} 4=$ row relay temulawak - jagung, $\mathrm{T} 5$ = strip relay jagung temulawak dan $\mathrm{T} 6=$ row relay jagung temulawak. Pola tanam strip cropping adalah penanaman beberapa tanaman sejenis secara beralur dan berselang seling dengan tanaman lain, sedangkan pola tanam row cropping adalah penanaman beberapa tanaman yang sama dalam barisan dan berselang seling dengan tanaman lain.

Penanaman temulawak secara strip (T1) dan row (T2) dilakukan secara bersamaan. 
Pada perlakuan relay cropping (T3 - T6), temulawak dan jagung ditanam secara bergiliran dengan selang waktu 1 bulan. Pada perlakuan $\mathrm{T} 3$ dan $\mathrm{T} 4$, tanaman temulawak ditanam lebih dulu dan 1 bulan kemudian dilakukan penanaman jagung. Pada perlakuan T5 dan T6, tanaman jagung ditanam lebih dulu dan 1 bulan kemudian dilakukan penanaman temulawak.

Populasi tanaman temulawak baik secara monokultur atau tumpangsari adalah 20 tanaman per plot, sedangkan populasi tanaman jagung pada pola pertanaman strip sebanyak 70 tanaman dan pertanaman row sebanyak 57 tanaman. Total populasi temulawak dan jagung pada pola pertanaman strip lebih banyak (90 tanaman) dibandingkan pola pertanaman row (77 tanaman). Jarak tanam yang digunakan dalam penelitian ini adalah: temulawak - temulawak $=50 \mathrm{~cm} \mathrm{x} 100 \mathrm{~cm}$, jagung - jagung $=25 \mathrm{~cm} \times 50 \mathrm{~cm}$ dan jagung temulawak $=25 \mathrm{~cm} \times 50 \mathrm{~cm}$ (pada pola tanam strip) dan temulawak - jagung $=50 \mathrm{~cm} \times 25$ $\mathrm{cm}$ (pada pola tanam row).

Pengamatan pertumbuhan pada tanaman temulawak meliputi panjang tanaman, jumlah daun dan luas daun yang dilakukan 2 minggu sekali, dimulai pada 1 bulan setelah tanam (bst). Pengamatan destruktif meliputi bobot segar rimpang dan bobot kering rimpang, hasil panen rimpang temulawak dilakukan sebanyak 1 kali saat panen 6 bst serta hasil panen jagung per hektar yang dipanen umur 105 hari setelah tanam (hst). Data yang didapatkan selanjutnya dianalisis menggunakan Analysis of Variance (ANOVA). Apabila terjadi pengaruh nyata pada perlakuan maka dilakukan uji lanjut dengan menggunakan BNT pada taraf 5\%.

\section{HASIL DAN PEMBAHASAN}

\section{Tinggi Tanaman Temulawak}

Tinggi tanaman merupakan parameter penting dari pertumbuhan dan perkembangan umum suatu tanaman yang menunjukkan adaptasi dan kekuatan tanaman pada berbagai kondisi lingkungan. Hasil penelitian menunjukkan bahwa tinggi tanaman semakin meningkat seiring dengan bertambahnya umur tanaman (Tabel 1).

Temulawak pada pola tanam strip dan row yang ditanam bersamaan serta pola tanam relay temulawak - jagung memiliki tinggi tanaman yang lebih tinggi dibandingkan dengan pola tanam yang lain (jagung temulawak). Hal ini disebabkan karena pada pola tanam tersebut dimungkinkan terjadi kompetisi cahaya antara temulawak dan jagung. Tanaman jagung menaungi temulawak, sehingga penerimaan cahaya oleh temulawak berkurang dan terjadi pemanjangan sel (etiolasi). Menurut Faiz et al. (2015), temulawak dapat tumbuh dengan baik dan dapat beradaptasi ditempat terbuka maupun di bawah tegakan pohon dengan tingkat naungan hingga $40 \%$. Hal ini sesuai dengan pendapat Kurniawati et al. (2005), yang menyatakan bahwa intensitas cahaya di bawah naungan $75 \%$ yang rendah dapat merangsang perpanjangan sel (etiolasi) serta meningkatkan panjang tangkai daun. Etiolasi terjadi karena adanya peningkatan sintesis auksin pada kondisi intensitas cahaya yang rendah (Gardner et al., 2008).

Tabel 1. Tinggi tanaman temulawak

\begin{tabular}{cccccccc}
\hline \multirow{2}{*}{$\begin{array}{c}\text { Perlakuan Pola } \\
\text { Tanam }\end{array}$} & \multicolumn{7}{c}{ Tinggi Tanaman $(\mathrm{cm})$ pada umur Pengamatan (MST) } \\
\cline { 2 - 8 } & 4 & 6 & 8 & 10 & 12 & 14 & 16 \\
\hline $\mathrm{T}_{1}=$ Strip cropping & $27.81 \mathrm{~b}$ & $44.00 \mathrm{~b}$ & $64.04 \mathrm{~b}$ & $80.29 \mathrm{~b}$ & $88.12 \mathrm{~b}$ & $90.00 \mathrm{~b}$ & $92.47 \mathrm{~b}$ \\
$\mathrm{~T}_{2}=$ Row cropping & $18.21 \mathrm{a}$ & $27.67 \mathrm{a}$ & $42.33 \mathrm{a}$ & $67.25 \mathrm{~b}$ & $75.63 \mathrm{~b}$ & $77.21 \mathrm{~b}$ & $80.29 \mathrm{~b}$ \\
$\mathrm{~T}_{3}=$ Strip relay $(\mathrm{T}-\mathrm{J})$ & $22.67 \mathrm{ab}$ & $31.25 \mathrm{ab}$ & $50.62 \mathrm{ab}$ & $73.75 \mathrm{~b}$ & $79.06 \mathrm{~b}$ & $81.67 \mathrm{~b}$ & $83.56 \mathrm{~b}$ \\
$\mathrm{~T}_{4}=$ Row relay $(\mathrm{T}-\mathrm{J})$ & $27.81 \mathrm{~b}$ & $34.17 \mathrm{ab}$ & $51.35 \mathrm{ab}$ & $73.75 \mathrm{~b}$ & $74.43 \mathrm{~b}$ & $83.64 \mathrm{~b}$ & $85.04 \mathrm{~b}$ \\
$\mathrm{~T}_{5}=$ Strip relay $(\mathrm{J}-\mathrm{T})$ & $22.62 \mathrm{ab}$ & $40.42 \mathrm{~b}$ & $46.25 \mathrm{ab}$ & $47.58 \mathrm{a}$ & $53.33 \mathrm{a}$ & $55.81 \mathrm{a}$ & $58.12 \mathrm{a}$ \\
$\mathrm{T}_{6}=$ Row relay $(\mathrm{J}-\mathrm{T})$ & $23.87 \mathrm{ab}$ & $43.37 \mathrm{~b}$ & $55.54 \mathrm{~b}$ & $57.75 \mathrm{ab}$ & $59.87 \mathrm{ab}$ & $60.75 \mathrm{ab}$ & $62.75 \mathrm{ab}$ \\
\hline BNT 5\% & 6.34 & 10.31 & 11.47 & 16.63 & 20.10 & 21.22 & 21.62 \\
\hline KK $(\%)$ & 20.61 & 21.67 & 17.20 & 19.31 & 21.71 & 21.96 & 21.74 \\
\hline
\end{tabular}

Keterangan: Bilangan yang diikuti huruf yang sama menunjukkan tidak berbeda nyata pada uji BNT 5\%. 
Pada pola tanam strip relay jagung temulawak dimana jagung ditanam lebih awal dari temulawak merupakan pola tanam dengan tinggi tanaman temulawak yang lebih rendah dibandingkan dengan perlakuan pola tanam yang lain. Hal ini terjadi karena dimungkinkan pada pola tanam tersebut terjadi kompetisi sumberdaya terbatas yaitu air, unsur hara, cahaya matahari serta ruang tumbuh antara tanaman utamanya pada fase periode kritis masing-masing tanaman. Periode kritis tanaman jagung adalah ketika berumur 0-1 bulan setelah tanam (bst), sedangkan temulawak ketika berumur 1-3 bst. Hal ini didukung oleh pernyataan Priambodo et al. (2010) yang menyatakan bahwa periode kritis terjadi pada saat $25-33 \%$ pertama pada siklus hidup tanaman atau $1 / 4-1 / 3$ pertama dari umur pertanaman.

Pada pola tanam ini, tanaman temulawak ditanam setelah tanaman jagung berumur 4 mst yang mengakibatkan jagung telah memiliki tajuk yang dapat menaungi temulawak dan memiliki perakaran yang lebih kuat dibandingkan temulawak. Hal ini sesuai dengan pernyataan Turmudi (2002) yang mengemukakan bahwa pada pola tumpangsari, tanaman yang ditanam lebih dahulu akan lebih diuntungkan karena lebih menguasai area tanam sehingga lebih kuat dalam berkompetisi. Yuliasari (2013) mengatakan bahwa tanaman yang sangat ternaungi akan mempunyai sistem perakaran lebih lemah dibandingkan dengan tanaman yang mendapat cahaya penuh. Selanjutnya dikatakan bahwa besarnya kompetisi ini tergantung kepada lamanya kompetisi dan daya kompetisi dari masingmasing tanaman yang ditumpangsarikan. Kebutuhan nutrisi, air dan cahaya matahari jagung lebih besar dibandingkan temulawak, sehingga dapat dikatakan bahwa pada pola tanam tersebut temulawak mengalami kekalahan kompetisi dalam perebutan sumberdaya terbatas.

\section{Jumlah dan Luas Daun Temulawak}

Daun merupakan organ utama yang berfungsi untuk menangkap cahaya yang kemudian digunakan untuk proses fotosintesis. Peningkatan jumlah daun berpengaruh pada peningkatan luas daun. Permukaan daun yang luas disertai dengan kandungan klorofil yang tinggi dapat meningkatkan penangkapan cahaya, sehingga proses fotosintesis dapat berjalan efisien dan menghasilkan asimilat yang optimum untuk pertumbuhan dan perkembangan tanaman (Sakya et al., 2008). Hasil penelitian ini menunjukkan bahwa jumlah daun (Tabel 2) dan luas daun (Tabel 3) semakin meningkat seiring dengan bertambahnya umur tanaman.

Sama halnya dengan tinggi tanaman, jumlah dan luas daun temulawak yang lebih tinggi terdapat pada pola tanam strip cropping, row cropping, serta strip dan row relay temulawak - jagung. Pertambahan tinggi tanaman temulawak menyebabkan jumlah daun yang terbentuk juga semakin banyak, karena daun merupakan organ yang terletak pada buku batang tanaman. Sakya et al. (2009), menyatakan bahwa semakin tinggi tanaman, maka daun yang terbentuk juga semakin banyak. Terdapat hubungan yang erat antara jumlah dan daun temulawak pada berbagai pola tanam yang disajikan pada Gambar 1. Kurniawati et al. (2005) yang menyatakan bahwa semakin banyak luas daun terbentuk, maka semakin besar luas daun total tanaman tersebut.

Tabel 2. Jumlah daun tanaman temulawak pada berbagai perlakuan pola tanam

\begin{tabular}{lccccccc}
\hline \multirow{2}{*}{$\begin{array}{c}\text { Perlakuan Pola } \\
\text { Tanam }\end{array}$} & \multicolumn{6}{c}{ Jumlah Daun Tanaman (helai) pada Umur Pengamatan (MST) } \\
\cline { 2 - 7 } & 4 & 6 & 8 & 10 & 12 & 14 & 16 \\
\hline T1 = Strip cropping & 2.8 & $4.3 \mathrm{~b}$ & $6.0 \mathrm{~b}$ & $7.8 \mathrm{~b}$ & $9.0 \mathrm{~b}$ & $9.5 \mathrm{~b}$ & $9.3 \mathrm{~b}$ \\
T2 = Row cropping & 2.5 & $3.3 \mathrm{a}$ & $4.8 \mathrm{a}$ & $7.5 \mathrm{~b}$ & $8.5 \mathrm{~b}$ & $9.0 \mathrm{~b}$ & $9.3 \mathrm{~b}$ \\
T3 = Strip relay (T-J) & 2.5 & $3.8 \mathrm{ab}$ & $6.0 \mathrm{~b}$ & $7.8 \mathrm{~b}$ & $8.5 \mathrm{~b}$ & $9.3 \mathrm{~b}$ & $9.3 \mathrm{~b}$ \\
T4 = Row relay (T-J) & 2.8 & $4.3 \mathrm{~b}$ & $6.5 \mathrm{~b}$ & $8.3 \mathrm{~b}$ & $9.2 \mathrm{~b}$ & $9.3 \mathrm{~b}$ & $9.3 \mathrm{~b}$ \\
T5 = Strip relay (J-T) & 2.5 & $4.5 \mathrm{~b}$ & $5.3 \mathrm{ab}$ & $5.8 \mathrm{a}$ & $7.0 \mathrm{a}$ & $7.5 \mathrm{a}$ & $7.5 \mathrm{a}$ \\
T6 = Row relay (J-T) & 2.8 & $4.5 \mathrm{~b}$ & $5.3 \mathrm{ab}$ & $6.5 \mathrm{a}$ & $7.5 \mathrm{a}$ & $7.8 \mathrm{ab}$ & $8.8 \mathrm{ab}$ \\
\hline BNT 5\% & tn & 0.8 & 0.8 & 1.2 & 0.8 & 1.5 & 1.5 \\
\hline KK $(\%)$ & 25.97 & 15.05 & 11.31 & 13.01 & 10.69 & 13.30 & 13.48 \\
\hline
\end{tabular}

Keterangan: Bilangan yang diikuti huruf yang sama menunjukkan tidak berbeda nyata pada uji BNT 5\%. tn = tidak nyata. MST= minggu setelah tanam. 
Tabel 3. Luas daun tanaman temulawak pada berbagai perlakuan pola tanam

\begin{tabular}{lrrrrrrr}
\hline \multirow{2}{*}{$\begin{array}{c}\text { Perlakuan Pola } \\
\text { Tanam }\end{array}$} & \multicolumn{6}{c}{ Luas Daun Tanaman $(\mathrm{cm} 2)$ pada Umur Pengamatan $(\mathrm{MST})$} \\
\cline { 2 - 8 } & 4 & 6 & 8 & 10 & 12 & 14 & 16 \\
\hline T1 = Strip cropping & $156.9 \mathrm{~b}$ & $401.8 \mathrm{~b}$ & $787.5 \mathrm{~b}$ & $1199.3 \mathrm{~b}$ & $1439.6 \mathrm{~b}$ & $1741.5 \mathrm{~b}$ & $1561.7 \mathrm{~b}$ \\
T2 = Row cropping & $82.5 \mathrm{a}$ & $211.7 \mathrm{a}$ & $556.0 \mathrm{ab}$ & $947 . \mathrm{b}$ & $1433.1 \mathrm{~b}$ & $1534.0 \mathrm{~b}$ & $1839.8 \mathrm{~b}$ \\
T3 = Strip relay $(\mathrm{T}-\mathrm{J})$ & $102.9 \mathrm{a}$ & $291.7 \mathrm{ab}$ & $699.8 \mathrm{~b}$ & $1229.9 \mathrm{~b}$ & $1625.8 \mathrm{~b}$ & $1933.4 \mathrm{~b}$ & $2046.4 \mathrm{~b}$ \\
T4 = Row relay $(\mathrm{T}-\mathrm{J})$ & $121.6 \mathrm{a}$ & $341.8 \mathrm{~b}$ & $790.5 \mathrm{~b}$ & $1242.8 \mathrm{~b}$ & $1858.5 \mathrm{~b}$ & $1952.8 \mathrm{~b}$ & $1975.8 \mathrm{~b}$ \\
T5 = Strip relay $(\mathrm{J}-\mathrm{T})$ & $88.8 \mathrm{a}$ & $220.3 \mathrm{a}$ & $437.9 \mathrm{a}$ & $569.5 \mathrm{a}$ & $727.6 \mathrm{a}$ & $811.0 \mathrm{a}$ & $827.2 \mathrm{a}$ \\
T6 = Row relay $(\mathrm{J}-\mathrm{T})$ & $96.5 \mathrm{a}$ & $277.8 \mathrm{ab}$ & $537.2 \mathrm{ab}$ & $805.5 \mathrm{ab}$ & $977.2 \mathrm{ab}$ & $1159.0 \mathrm{ab}$ & $1178.8 \mathrm{ab}$ \\
\hline BNT 5\% & 40.9 & 103.9 & 235.2 & 330.4 & 582.0 & 653.7 & 529.11 \\
\hline KK $(\%)$ & 29.26 & 30.33 & 28.70 & 25.61 & 22.08 & 22.63 & 26.07 \\
\hline K & &
\end{tabular}

Keterangan: Bilangan yang diikuti huruf yang sama menunjukkan tidak berbeda nyata pada uji BNT 5\%. MST= minggu setelah tanam.

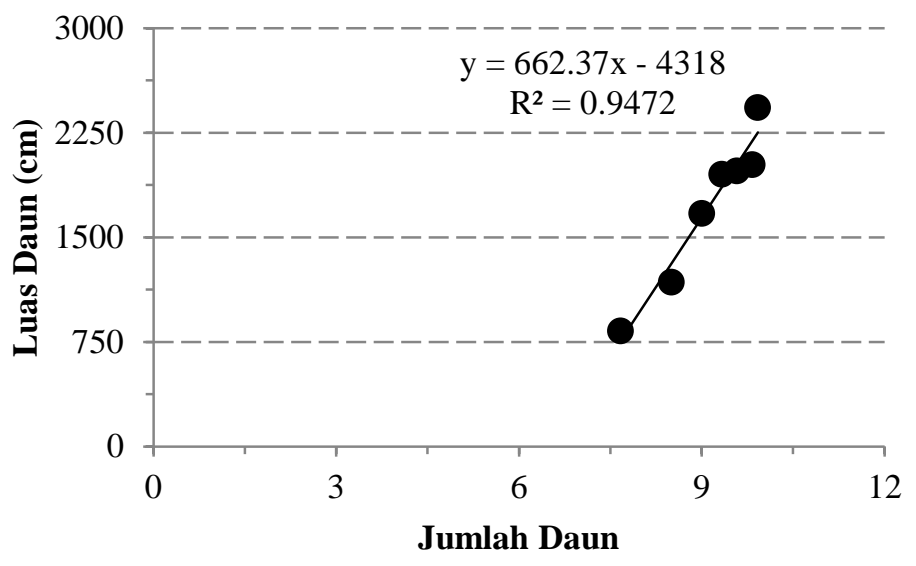

Gambar 1. Hubungan jumlah dan luas daun temulawak pada berbagai pola tanam dengan jagung

Jumlah daun terendah terdapat pada pola tanam strip relay jagung - temulawak (Tabel 2). Pola tanam ini memiliki jarak tanam antara tanaman temulawak dan jagung yang sempit serta kepadatan populasi yang lebih tinggi, sehingga terjadi kompetisi sumberdaya terbatas seperti air, unsur hara dan cahaya matahari. Jarak tanam yang terlalu sempit akan menyebabkan persaingan yang tinggi, sehingga mengakibatkan pertumbuhan dan produktivitas menjadi rendah. Selain itu, hal lain yang perlu diperhatikan dalam pola tumpangsari adalah waktu tanam, karena waktu tanam berhubungan dengan pertumbuhan vegetatif (Herlina, 2011). Pada pola tanam ini juga terjadi perbedaan waktu tanam antara temulawak dan jagung, dimana temulawak ditanam ketika jagung telah berumur 4 minggu setelah tanam (mst). Pertumbuhan vegetatif jagung yang lebih cepat dan lebih dominan menguasai ruang, mengakibatkan jagung lebih mampu berkompetisi dalam memperebutkan air, unsur hara dan cahaya dibandingkan dengan pertumbuhan vegetatif temulawak yang lambat, sehingga mempengaruhi pertumbuhan tanaman temulawak seperti jumlah dan luas daun yang rendah yang nanti juga akan berpengaruh terhadap produksi.

\section{Hasil dan Komponen Hasil Temulawak}

Produksi merupakan komponen hasil utama dalam sebuah sistem budidaya tanaman. Dari hasil penelitian, diketahui bahwa bobot segar dan kering rimpang tertinggi terdapat pada pola tanam row cropping, sedangkan yang terendah adalah pada pola tanam strip dan row relay jagung - temulawak (Tabel 4). Hal ini terjadi karena pola tanam row cropping memiliki biomassa tanaman temulawak (bobot segar dan kering total tanaman) yang lebih tinggi, sehingga segar basah dan kering rimpang temulawak yang dihasilkan juga tergolong tinggi yang mempengaruhi hasil panen rimpang temulawak per hektar (Gambar 2). Hal ini didukung dengan pernyataan Sitompul (2015) yang menyatakan bahwa 
salah satu faktor pertumbuhan tanaman yang menentukan produksi hasil tanaman tergantung pada produksi biomassa tanaman dan kapasitas sink. Selain itu, fase periode kritis juga memberikan pengaruh yang besar terhadap pertumbuhan dan hasil tanaman temulawak tersebut.

Kompenen pertumbuhan (tinggi tanaman, jumlah dan luas daun) yang lebih rendah pada pola strip dan row relay jagung - temulawak berpengaruh pada rendahnya bobot segar dan kering rimpang serta hasil panen per hektarnya. Jagung yang ditanam satu bulan lebih awal dibanding temulawak telah melewati fase periode kritis dan sudah siap berkompetisi, sedangkan temulawak yang baru ditanam masih dalam fase periode kritis dan masih membutuhkan lebih banyak sumberdaya terbatas untuk menunjang pertumbuhannya. Periode kritis adalah periode maksimum dimana setelah periode tersebut dilalui maka keberadaan gulma atau tanaman lain selanjutnya tidak terpengaruh terhadap hasil akhir (Priambodo et al., 2010). Pemilihan jenis tanaman sesuai dengan periode kritisnya dan jarak tanam yang tepat berpengaruh terhadap pertumbuhan vegetatif yaitu pertumbuhan jumlah daun dan jumlah cabang, serta bobot panen cenderung meningkat pada tanaman kenikir (Himma dan Purwoko, 2013). Fase periode kritis tanaman jagung adalah pada umur 0-1 bst, sedangkan temulawak pada umur 0-3 bst yang dapat diartikan bahwa keadaan inilah yang membuat pertumbuhan temulawak pada pola tanam strip dan row relay jagung - temulawak menjadi terhambat, sehingga menghasilkan produksi yang sangat rendah dibandingkan dengan pola tanam yang lain.

Tabel 4. Bobot segar dan bobot kering rimpang tanaman temulawak pada berbagai perlakuan pola tanam

\begin{tabular}{ccc}
\hline Perlakuan Berbagai Pola Tanam & $\begin{array}{c}\text { Bobot Segar } \\
\text { Rimpang }\left(\mathrm{g} \cdot \tan ^{-1}\right)\end{array}$ & $\begin{array}{c}\text { Bobot Kering } \\
\text { Rimpang }\left(\mathrm{g} \cdot \tan ^{-1}\right)\end{array}$ \\
\hline T1 $=$ Strip cropping & $125.62 \mathrm{c}$ & $29.01 \mathrm{c}$ \\
T2 $=$ Row cropping & $190.17 \mathrm{~d}$ & $43.00 \mathrm{~d}$ \\
T3 $=$ Strip relay $(\mathrm{T}-\mathrm{J})$ & $78.82 \mathrm{~b}$ & $19.48 \mathrm{~b}$ \\
T4 $=$ Row relay $(\mathrm{T}-\mathrm{J})$ & $80.04 \mathrm{~b}$ & $20.30 \mathrm{~b}$ \\
T5 $=$ Strip relay $(\mathrm{J}-\mathrm{T})$ & $13.52 \mathrm{a}$ & $3.15 \mathrm{a}$ \\
T6 $=$ Row relay $(\mathrm{J}-\mathrm{T})$ & $32.65 \mathrm{a}$ & $9.04 \mathrm{a}$ \\
\hline BNT 5\% & 27.79 & 7.04 \\
\hline KK $(\%)$ & 24.79 & 26.49 \\
\hline
\end{tabular}

Keterangan: Bilangan yang diikuti huruf yang sama menunjukkan tidak berbeda nyata pada uji BNT 5\%.

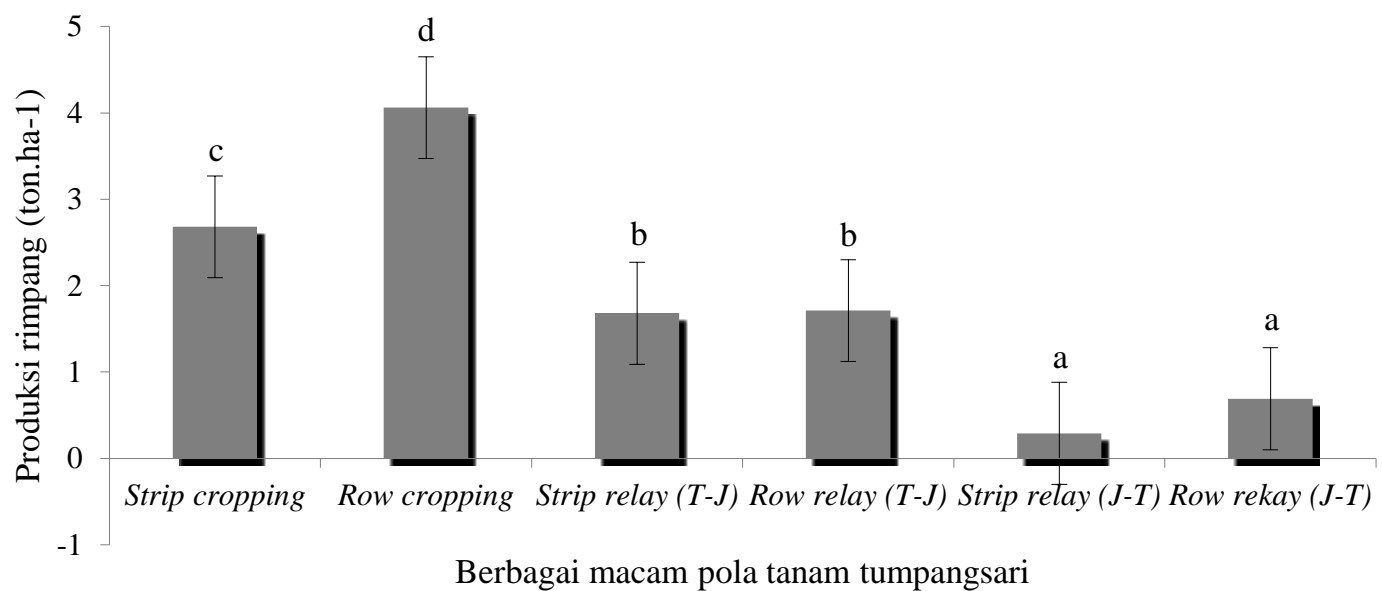

Keterangan: Grafik yang didampingi huruf yang sama pada setiap perlakuan menunjukkan pengaruh yang tidak berbeda nyata berdasarkan uji BNT $5 \%$.

Gambar 2. Hasil panen temulawak per hektar 
Hal yang berbeda terjadi pada pola tanam row cropping antara tanaman temulawak dan jagung dimana keduanya ditanam pada waktu yang bersamaan. Pada pola tanam ini kedua tanaman melewati fase periode kritis yang bersamaan dari awal pertumbuhannya, sehingga kedua tanaman tersebut baik temulawak maupun jagung lebih tahan terhadap kompetisi sumberdaya terbatas (air, nutrisi, cahaya matahari).

\section{Hasil Panen Jagung}

Hasil panen kering tongkol jagung yang lebih tinggi terdapat pada pola tanam strip relay temulawak - jagung, sedangkan yang lebih rendah adalah pola tanam row cropping dan row relay jagung - temulawak (Gambar 3). Hal ini disebabkan karena pada pola tanam strip relay temulawak - jagung memiliki nilai komponen pertumbuhan (tinggi tanaman, jumlah serta luas daun) yang lebih tinggi dibandingkan pola tanam lainnya, sehingga menghasilkan bobot kering tongkol jagung per hektar yang lebih tinggi. Sebaliknya, jika komponen pertumbuhan jagung pada pola pertanaman tertentu rendah, maka bobot kering tongkol jagung per hektar yang dihasilkannya juga akan rendah. Sitompul (2015) menyatakan bahwa produksi biomassa tanaman tergantung pada kapasitas sink dan kerja komponen-komponen pertumbuhan tanaman, dalam hal ini misalnya tinggi tanaman, jumlah serta luas daunnya.
Rendahnya hasil tanaman jagung pada pola tanam row relay jagung - temulawak diduga karena adanya gangguan pada perakaran jagung yang saat itu berumur $4 \mathrm{mst}$ karena aktivitas penanaman temulawak. Hernawati (2016) menyatakan bahwa hal yang juga perlu diperhatikan dalam pola tanam tumpangsari adalah sistem perakaran tanaman. Apabila terjadi gangguan pada perakaran tanaman jagung, maka proses penyerapan nutrisi dan air oleh akar juga akan terganggu, sehingga pertumbuhan tanaman akan terganggu dan hasil tanaman juga lebih rendah. Hal ini sesuai dengan pernyataaan Setiawan (2009) yang menyatakan bahwa suplai air dan hara akan terhambat jika perakaran tanaman terganggu, yang mengakibatkan pertumbuhan tanaman juga terhambat dan produksi yang dihasilkannya rendah.

\section{Nisbah Kesetaraan Lahan (NKL)}

Nisbah Kesetaraan Lahan (NKL) diperoleh dengan cara membandingkan hasil pertanaman tumpangsari temulawak dan jagung dengan pertanaman tunggal tanaman penyusunnya. Hasil perhitungan nilai NKL menunjukkan bahwa pola tanam strip cropping, row cropping dan strip relay temulawak - jagung memiliki nilai NKL lebih dari 1.00 dan lebih tinggi dibandingkan dengan pola tanam yang lain (Tabel 5).

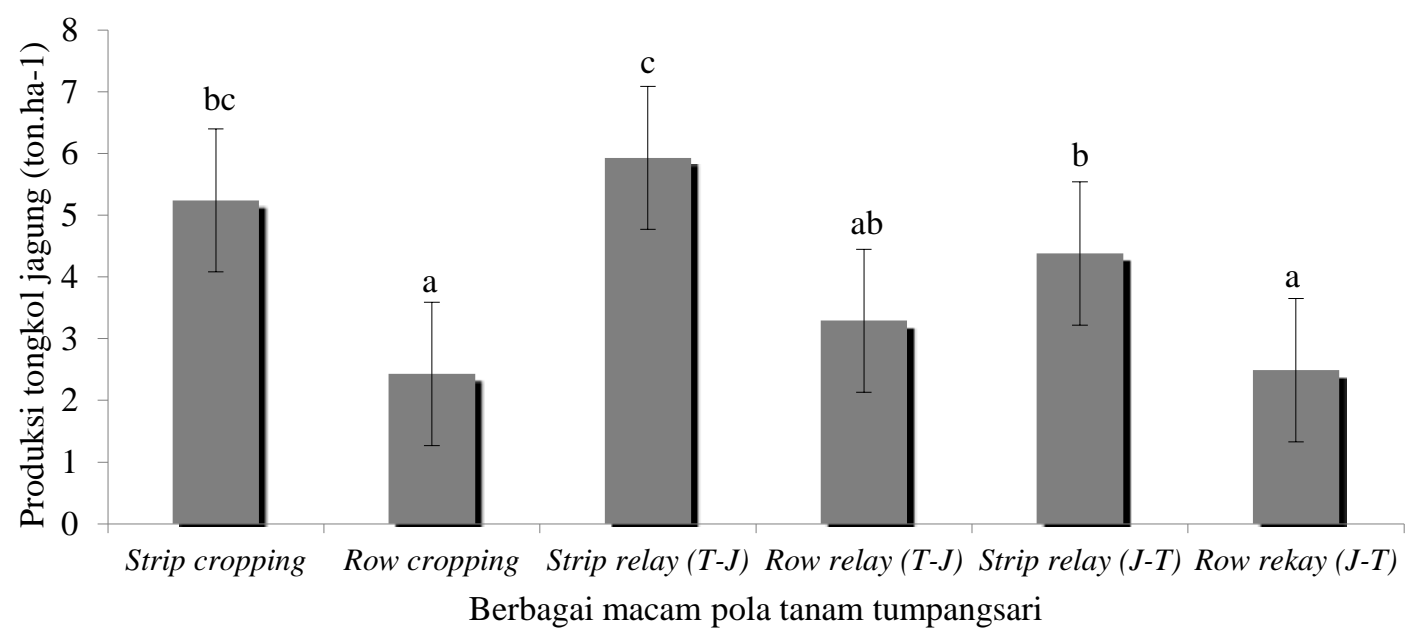

Keterangan: Grafik yang didampingi huruf yang sama pada setiap perlakuan menunjukkan pengaruh yang tidak berbeda nyata berdasarkan uji BNT 5\%.

Gambar 3. Hasil panen jagung per hektar 
Tabel 5. Nisbah kesetaraan lahan

\begin{tabular}{cc}
\hline $\begin{array}{c}\text { Perlakuan Berbagai } \\
\text { Pola Tanam }\end{array}$ & $\begin{array}{c}\text { Nilai rata-rata } \\
\text { Nisbah Kesetaraan } \\
\text { Lahan }(\mathrm{NKL})\end{array}$ \\
\hline $\mathrm{T}_{1}=$ Strip cropping & $1.22 \mathrm{c}$ \\
$\mathrm{T}_{2}=$ Row cropping & $1.07 \mathrm{c}$ \\
$\mathrm{T}_{3}=$ Strip relay $(\mathrm{T}-\mathrm{J})$ & $1.14 \mathrm{c}$ \\
$\mathrm{T}_{4}=$ Row relay $(\mathrm{T}-\mathrm{J})$ & $0.77 \mathrm{~b}$ \\
$\mathrm{~T}_{5}=$ Strip relay $(\mathrm{J}-\mathrm{T})$ & $0.67 \mathrm{ab}$ \\
$\mathrm{T}_{6}=$ Row relay $(\mathrm{J}-\mathrm{T})$ & $0.48 \mathrm{a}$ \\
\hline BNT 5\% & 0.18 \\
\hline KK $(\%)$ & 13.12 \\
\hline
\end{tabular}

Keterangan: Bilangan yang diikuti huruf yang sama menunjukkan tidak berbeda nyata pada uji BNT 5\%.

Hal ini menunjukkan bahwa ketiga sistem tanam tersebut dinilai mampu meningkatkan produktivitas lahan sehingga lebih efisien dibandingkan sistem pertanaman monokultur (Karima et al., 2013).

\section{KESIMPULAN}

Perbedaan pola tanam pada sistem tumpangsari temulawak dan jagung memberikan pengaruh yang berbeda bagi pertumbuhan dan hasil temulawak. Temulawak yang ditanam lebih awal memiliki nilai rata-rata pertumbuhan dan hasil yang lebih baik jika dibandingkan dengan temulawak yang ditanam setelah jagung. Row cropping merupakan pola tanam yang memberikan hasil rimpang temulawak tertinggi dibanding pola tanam lainnya yang mencapai 4.05 ton $\mathrm{ha}^{-1}$ Strip cropping, Row Cropping dan Strip relay temulawak - jagung memberikan nilai kesetaraan lahan $>1.00$.

\section{DAFTAR PUSTAKA}

Akamine, H., M.A. Hossain, Y. Ishimine, K. Yogi, K. Hokama. 2007 effects of application of $\mathrm{N}$, and alone or in combination on growth, yield and curcumin content of turmeric. Plant Prod. Sci. 10(1): 151-154.

Faiz, H., I. Thohari, Purwadi. 2015. Pengaruh penambahan sari temulawak (Curcuma xanthorriza Roxb.) terhadap total fenol, kadar garam, kadar lemak dan tekstur telur asin. J. Ilmu-ilmu Peternakan.
24(3): 39. ISSN: 0852-3581. Fakultas Peternakan Universitas Brawijaya.

Gardner, F.P., R.B. Pearce, R.L. Mitchell. 2008. Fisiologi Tanaman Budidaya. Penerjemah: Susilo H. Subiyanto. UI Prees. Jakarta. 428 hlm.

Hasan, A. 2013. Pengaruh variasi jarak tanam dan varietas terhadap pertumbuhan dan hasil tanaman jagung manis (Zea mays saccharata Sturt). kim.ung.ac.id/index. php/KIMFIIP/article/download/2470/24 49. [20 Januari 2015].

Herlina. 2011. Kajian variasi jarak dan waktu tanam jagung manis dalam sistem tumpangsari jagung manis (Zea mays saccharta Sturt) dan kacang tanah (Arachis hypogaea L). Universitas Andalas. Padang. http://pasca.unand. ac.id/id/wpcontent/uploads/2011/09/KA JIANVARIASI-JARAK-DANWAKTUTANAM.pdf. [14 November 2015].

Hernawati, D.T. 2016. Kajian ekonomi antara pola tanam monokultur dan tumpangsari tanaman jagung, kubis dan bayam. INOVASI. 18(1): 66-71.

Himma, F., B.S. Purwoko. 2013. Pengaruh jarak tanam terhadap produksi tiga sayuran indigenous. J. Hort. Indonesia. 4(1): 26-33.

Karima, S.S., M. Nawawi, N. Herlina. 2013. Pengaruh saat tanam jagung dalam tumpangsari tanaman jagung (Zea mays L.) dan brokoli (Brassica oleraceae L. var. botrytis). J. Prod. Tan. 1(3): 87-92.

Kurniawati, A., L.K. Darusma, R.Y. Rachmawaty. 2005. Pertumbuhan, produksi dan kandungan triterpenoid dua jenis pegagan (Centella asiatica $\mathrm{L}$. (Urban)) sebagai bahan obat pada berbagai tingkat naungan. Bul. Agron. 33(3): 62-67.

Nihayati, E., T. Wardiyati, Soemarno, R Retnowati. 2013. Rhizome yield of temulawak (Curcuma xanthorrhiza Roxb.) at N, P, K various level and N, K combination. J. Agrivita 35(1): 1-11. 
Priambodo, A., B. Guritno, A. Nugroho. 2010. Upaya peningkatan pertumbuhan dan hasil tanaman kedelai (Glycine max) melalui aplikasi mulsa daun jati dan pupuk organik cair. pustakapertanianub. staff.ub.ac.id/files/2012/01/Jurnal2.pdf. [25 Januari 2015].

Rahardjo, M. 2010. Penerapan SOP budidaya untuk mendukung temulawak sebagai bahan baku obat potensial. Perspektif. 9(2): 78-93.

Rahardjo, M., R.P. Ekawasita. 2010. Pengaruh pupuk urea, SP36 dan $\mathrm{KCl}$ terhadap pertumbuhan dan produksi temulawak. J. Littri. 16(3): 98-105.

Sakya, A. T., M. Rahayu, R. Wijayanti. 2008. Pertumbuhan dan kualitas Anthurium hookeri pada berbagai pemberian Boron. Sains Tanah - Jurnal Ilmiah Ilmu Tanah dan Agroklimatologi. 5(2): 9599.

Sakya, A.T., D. Purnomo, F. Fahruddin. 2009. Penggunaan ekstrak teh dan pupuk kascing pada budidaya Caisim (Brassica juncea L.). J. Ilmu Tanah dan Agroklimatologi. 6(2): 61-68.
Sitompul, S.M. 2015. Analisis Pertumbuhan Tanaman. UB Press. Malang. pp. 210.

Suwarto, S. Yahya, Handoko, M.A. Chozin. 2005. kompetisi tanaman jagung dan ubikayu dalam sistem tumpang sari. Bul. Agron. 33(2): 1-7.

Syakir, M., N. Maslahah. M. Januwati. 2008. Mix cropping system for Zingiberaceae for up land site and dry agro-ecological zone of East Java. Proceeding of the First International Symposium on Temulawak. Biopharmaca Research Center Bogor Agricultural University, p. 285-289.

Turmudi, E. 2002. Kajian pertumbuhan dan hasil tanaman dalam sistem tumpangsari jagung dengan empat kultivar kedelai pada berbagai waktu tanam. J. IlmuIlmu Pertanian Indonesia. 4(2): 89-96.

Yuliasari, R. 2013. Distribusi bahan kering beberapa genotipe sorgum (Sorghum bicolor [L.] Moench) yang ditumpangsarikan dengan ubikayu (Manihot esculenta Crantz.). [Skripsi]. Fakultas Pertanian. Universitas Lampung. digilib.unila.ac.id/1081/3/BAB\%20II.pd f. [15 November 2015]. 